avoiding the current insistence that 'you can only go if you are going to read a paper'-a reprehensible form of activity in any event.

Mr. A. V. S. de Reuck (Ciba Foundation) argued that to-day scientific communications are addressed less to scientists at large than to what Price has called "invisible colleges" of one's peers in the field ${ }^{5}$, and this is achieved either by circulating reprints or by attending symposia. Whether one likes it or not, scientific journals nowadays function chiefly as archives and the most effective channel of communication is through small élite gatherings, whose published proceedings serve both to map a whole sector of the frontier of knowledge and to display recent work in its context, giving it a deeper significance which is particularly valuable for scientists situated far from the metropolitan centres of research, especially those in developing countries. The 'didactic deadpan' style, in which almost all scientific work is reported ${ }^{6}$ and which conceals the true nature of science, is partly relieved in such publications by verbatim reports of discussions, and this, he thought, is valuable in humanizing scientific writing. On one hand, there seems little to be said in favour of staging, let alone publishing, gargantuan congresses; on the other hand, it would be a retrograde step to confine symposium reports to the journals, the functions of which are changing and the former role of which is gradually being taken over by symposia. In these circumstances certain journals, including Nature, acquire a new significance in the wider dissemination of important news and discoveries.

${ }^{1}$ Walshe, F. M. R., Perspectives in Biology and Medicine, 202 (Chicago University Press, Chicago, 1959)

${ }^{2}$ Brown, G. L., Nature, 193, 724 (1962).

${ }^{3}$ Ziman, J. M., Bull. Inst. Phys. and Phys. Soc., 13, 196 (1962).

${ }^{4}$ Editorial, Nature, 193, 708 (1962).

$\checkmark$ Price, D. J. de S., Little Science, Big Science (Columbia University Press, New York and London, 1963).

- Watkins, J. W. N., The Listener, 69, 667 (1963).

\title{
OBITUARIES
}

Prof. S. W. Wooldridge, C.B.E., F.R.S.

Prof. S. W. Wooldridge, professor of geography in King's College, University of London, died suddenly on April 25 at the age of sixty-two.

Sidney William Wooldridge was born on November 16 , 1900. From Glendale County School, Wood Green, he entered King's College, London, and took a first-class honours degree in geology in 1921, following with his M.Sc. in 1923 and his D.Sc. in 1927. He joined the staff of the Department of Geology and Geography in 1922 as a demonstrator, being appointed lecturer in 1927 and reader in 1942 . In 1944 he was appointed to the chair of geography at Birkbeck College, and, although he held this position for only three years, he maintained his contacts with Birkbeck College and was honorary lecturer in geography there. Nevertheless, he regarded himself essentially as a King's College man, and welcomed the opportunity of returning to King's College in 1947 as professor when the chair of geography was revived after an interval of seventy years. Earlier, when King's College was evacuated to Bristol during the War, he had to shoulder the entire teaching burden of the Geography Department, and this period confirmed his status as one of the leading British geographers with an all-round mastery of his subject equalled by few.

The Joint School of Geography, consisting of the Departments at King's College and at the London School of Economics, kept him in close contact with the economic and social sides of geography, and he was an ardent believer in the value of comprehensive regional studies. His faith in the primary importance of the physical basis of geography nevertheless remained firm, and to him belongs much of the credit for the maintenance in Britain of the strong physical roots of geography in the face of a tendency in the subject for greater emphasis to be laid elsewhere. He never failed to stress that geography is a field science, and his teaching in the field was an inspiration to countless students. He played a major part in the early work and progress of the Field Studies Council, which through its residential centres revolutionized sixthform teaching in the field sciences. His books included The Geographer as Scientist, a collection of some of his papers, Structure, Surface and Drainage in South East England (with D. Linton), Introduction to Geomorphology (with R. S. Morgan), The Weald (with F. Goldring), London's Countryside (with G. E. Hutchings), and The Spirit and Purpose of Geography (with W. G. East).

The London Basin and the Weald were his particular interest, and his name will always be associated with these. His early work on the quaternary geology of south-east England led him to the realization of hitherto unexplained problems of the landforms of the area. Basing his ideas on the early physiographic studies of Davis and others, he began a new appreciation of these problems, and threw new light on the origins of the river systems, unravelling the complicated pattern of the denudation chronology of the whole region. From this work, published jointly with Linton, he extended his studies to other parts of the country, with far-reaching results. His findings revolutionized the subject, transforming landform study from the older descriptive physiography into the live science of geomorphology, standing in its own right as a systematic discipline. In his field he was unrivalled, brilliant in his appreciation of landform, and, through the many students whom he inspired, his analytical methods and techniques brought a new approach to the study of physical geography in Britain. The record of achievement in this field over the past quarter of a century is largely the result of Wooldridge's work, and will stand as a lasting testimony to his outstanding reputation.

The distinction of his work was repeatedly recognized: the Geological Society of London awarded him a grant from the Daniel Pigeon Fund in 1928, and from the Lyell Geological Fund in 1936; he received the Foulerton Award in 1932 from the Geologists' Association; the Royal Geographical Society made him the Murchison Grant (jointly with Linton) in 1942, and awarded him the Victoria Medal in 1957. He was elected a Fellow of the Royal Society in 1959. For his work with the Advisory Committee on Sand and Gravel he received the C.B.E. He was at times president of the Institute of British Geographers, of Section E (Geography) of the British Association for the Advancement of Science, and of the Geographical Association. Possibly his greatest pleasure came from his election to a fellowship at King's College in 1956 and to the presidency of the King's College London Association in his last year.

Outside his work his interests were numerous. He was a governor of Sir John Cass College and of Wye College, and gave many years of active support to the Working Men's College. His theological knowledge was great, and he was a sincere Christian. For many years he was a lay preacher in the Congregational Church, and he was received into the Anglican Communion a year before his death. He will be remembered with affection for his enthusiasm for Gilbert and Sullivan: he was one of the founders of the Geoids, a light operatic society originally recruited from the Departments of Geology and Geography of King's College, and his production of The 
Pirates of Penzance by the College Music Society in March of this year gave enjoyment to many people. A keen cricketer in his youth, he still delighted in a day at the Oval and enjoyed demonstrating the art of spin bowling to other enthusiasts.

A serious illness in 1954 had left him in indifferent health in his latter years, and it was a matter of grief to him that he had to restrict his research work and teaching in the field; but he continued to exert himself unsparingly, and had returned from a first-year field class only two days before his death.

Widely regarded with both respect and affection, he will long be remembered for his eminence as a geographer, and by the great number of students and colleagues in whose problems he took such great personal interest and to whom he showed such great generosity of spirit. J. C. P.

\section{Prof. A. Geiger}

The death of Alexander Geiger, for the past ten years professor of neurophysiology in the University of Illinois College of Medicine in Chicago, marks the passing of an unusually talented and imaginative scientist. Born in Hungary, where he started his medical training, he then continued his studies under Biedl in Prague and Botazzi in Naples. He joined the staff of the Hebrew University of Jerusalem in 1927 and participated in a number of practical investigations dealing with the relation between diet and climate in Palestine in disorders of the infant. He then went on to more basic physiological studies and in 1931 published a method for the ultra-filtration of blood in vivo and a classical paper on the separation by electrophoresis of two oxyhæmoglobins from adult blood of a number of species, which was published in the Proceedings of the Royal Society and introduced by the then secretary, Sir Henry Dale.

In 1934 Prof. Geiger established the Department of Physiology of the Hebrew University in half a room of the old Sir John Grey Hill house on Mount Scopus. His staff consisted of a technician and student volunteer. He was equally at home in physiology and biochemistry, and from then on his main interest became the biochemistry of the nervous system, which at that time was practically untrodden ground. This was typical of his pioneering approach to his scientific work. He was not one to climb aboard the fashionable 'band-wagons'. He was not afraid of difficulties and was not out for quick returns in the form of publications. His scientific curiosity always took the upper hand, and he had the audacity to enter an unknown field and the tenacity to stick to it despite pitfalls and obstacles.

After making significant contributions to the biochemistry of the brain in vitro, the most important being the preparation of a metabolically active brain extract, he began to feel that pure biochemical methods could not contribute sufficiently to the understanding of brain functions. Consequently, he did not hesitate to embark on revolutionary experiments in which the circulation of the living brain was isolated and the brain supplied with blood of known composition. Thus the advantages of the physiological and biochemical approaches were combined. It took five years to work out the 'brain perfusion method', but later Geiger's metabolic investigations with this technique became his chef d'oeuvre until his untimely death, and it is for this work that his name will be mainly remembered in the scientific world. He published some thirty papers and twenty shorter notes on this topic, and through his efforts became one of the most effective links between the biochemist and the physiologist interested in the brain.

Geiger was a great enthusiast with the quality of inspiring his colleagues. He was an outstanding example of fairness, always giving credit where credit was due. In many ways he had an artistic temperament which helped pave the way for his highly original ideas. He had a seething mind, and it was always stimulating to discuss one's research with him, no matter what the topic. $\mathrm{He}$ had an inner resistance to the conventional and did not allow himself to become an administrator, which is the lot of many a leading scientist in this day and age, but continued to experiment with his own hands until the last day.

Geiger had a great love for the outdoors which he developed in the Carpathian Mountains in his youth, and he had tramped the countryside of Israel from end to end. He was a talented amateur painter and cook, had a highly developed sense of humour and appreciated art, music and good food. He will be greatly missed by his colleagues and family.
J. Magnes

\section{NEWS and VIEWS}

Biophysics and Physical Biochemistry at Pennsylvania : Prof. Q. H. Gibson

Prof. Q. H. GIBson recently resigned from the chair of biochemistry at Sheffield following his appointment as professor of biophysics and physical biochemistry in the Johnson Research Foundation of the University of Pennsylvania School of Medicine and professor of physiology in the Graduate School of Medicine. Before his appointment to the chair at Sheffield in 1955, he was senior lecturer in physiology at Sheffield. Prof. Gibson is well known for his contributions to rapid reaction techniques and their application to the kinetic study of hæmoproteins. His modification of the stopped-flow method of Chance and application of flash photolysis to the rapid dissociation of carbon monoxide compounds of hæmoproteins gave a new impetus to the kinetic investigation of these compounds. By these methods he has studied the reactions of hæmoglobins and myoglobin with oxygen, carbon monoxide and other ligands, and the combination of globin and hæms, and obtained quantitative data of importance for the understanding of the relations between structure and function of hæmoproteins. His collaboration with Prof. F. J. W. Roughton in the evaluation of the intermediate compound theory of the reactions of mammalian hæmoglobin cul- minated in the estimation of the individual velocity constants for the successive reactions of carbon monoxide with the four hæms of sheep hæmoglobin. Prof. Gibson has recently applied the method of flash photolysis to the important problem of the nature and mode of action of the hæm-enzyme cytochrome oxidase. His recent work on flavin oxidation and the mechanism of action of the flavin-containing enzyme lipoyl dehydrogenase, in collaboration with Dr. V. Massey, has demonstrated the value of the stopped-flow method, in conjunetion with other techniques, as a tool for the intimate study of this group of enzymos also.

\section{Mount Wilson and Palomar Observatories, California}

Dr. Horace W. BABCock, noted for his observations of the magnetic fields of the Sun and stars, has been appointed director of Mount Wilson and Palomar Observatories in succession to Dr. Ira S. Bowen, who retires on June 30, 1964. These Observatories are operated jointly by the Carnegie Institution of Washington and California Institute of Technology. Dr. Bowen has been director of both Observatories since Palomar Observatory was established in 1948 and was director of Mount Wilson Observatory for two years before that. He has been a member of staff of the California Institute 